\title{
IRONIC ALLUSION AND THE HUMAN MIND IN CALDERÓN'S LA CISMA DE INGLATERRA
}

A05411 Calderón works three remarkable allusions into speeches made in Act I of his Henry VIII play, La cisma de Inglaterra (c. 1627). In two cases a character is linked to a figure from classical mythology and in one to a figure from the Bible. Each allusion is economically worded yet each has the potential to speak volumes. First, Enrique implicitly likens himself to Mars, the Roman god of war (ll. 77-79). ${ }^{1}$ This is entirely unsurprising: the king means to suggest, conventionally, that he is a superlative military leader. Second, the French ambassador, Carlos, connects the object of his affections to the peacock, a bird associated with the Roman goddess Juno, meaning thereby to convey a sense of Ana Bolena's beauty and pride (1l. 353-56). Third, Queen Catalina (Katherine of Aragon) draws a parallel between herself and the Old Testament figure of Esther, confident that Enrique's severe strictures do not bind her and that she will precipitate the downfall of Volseo (Wolsey), whom she casts as the wicked Aman, chief counsellor to the Persian King Assuerus (11. 669-72). I shall argue that in each case the text invites the oyente quickly to grasp the exquisite irony of these allusions. They are ironic because the engaged spectator will understand the characters to reveal unwittingly something rather different from the things ostensibly intended. Once these embryonic allusions are fleshed out in the spectator's mind and once analogies are drawn between the pertinent classical and biblical tales, on the one hand, and Henry's Great Matter, on the other, it becomes clear that they are far more apposite than when taken at face value. This essay will demonstrate that these allusions are devastatingly apt for reasons that, in the early scenes during which they are deployed, the characters cannot easily comprehend. As is often the case with historical plays, the well-informed spectator is at an advantage, familiar already with the gist of the episode being dramatized. If thoroughly interpreted, these three allusions can point forward to the drama's desenlace and, in the case of Juno's peacock, to salacious rumours which, for the sake of decorum, Calderón prefers to share, not explicitly, but with a learned nod and a wink.

Calderón's three ironic allusions have several functions. They create dramatic irony, certainly: from an early stage the audience gains an inkling of the fates that will befall the characters present before it on the tablado, fates largely in keeping with the historical record. The spectator must watch, powerless, as each protagonist-condemned to exercise God-given free will

\footnotetext{
${ }^{1}$ Quotations from La cisma are taken from Calderón de la Barca, La cisma de Ingalaterra, ed. by Juan Manuel Escudero Baztán, Teatro del Siglo de Oro, Ediciones críticas, 115 (Kassel: Reichenberger, 2001).
}

Modern Language Review, 111 (2016), 1004-28

(C) Modern Humanities Research Association 2016 
informed by only finite knowledge and a limited perspective-contributes to the maelstrom that engulfs them all. It seems to me, however, that these ironic allusions also create an impression of psychological depth and constitute an underappreciated technique of characterization in Calderón's drama. The technique is not so subtle that the reasonably cultured among his original spectators would have failed to apprehend its effects. Following discussion of the allusions' irony, this essay will demonstrate that the classical and biblical knowledge required for the oyente to detect it was, in Golden Age Spain at least, not at all recondite but was, in the main, closer to being commonplace. As for knowledge of Henry's Great Matter, according to the modern editor of Calderón's source text, Pedro de Rivadeneira's Historia eclesiástica del cisma del reino de Inglaterra (Part I, 1588), this account of Henry's reign was from its first appearance 'una de las obras más populares de España'. ${ }^{2}$

The characterization technique to which I refer shows Calderón to be a thoughtful painter of the shadowy workings of the human mind, a matter of considerable interest in seventeenth-century Europe. While it is clear that Enrique, Catalina, and Carlos are ignorant of the full ramifications of the analogies they draw, there is evidence that permits the spectator to understand that, in some difficultly tangible way, the precise choices of allusion made by them spring from what might be described today as their unconscious minds, 'where desire dominates and even thoughts are beyond human control'. ${ }^{3}$ It is in the characters' unconscious minds, as glimpsed through the allusions, that actions at the start of La cisma, or in the prehistory, are shown to have begun to stir certain impulses some time before the characters are seen to have gained an active awareness of the implications of the rapidly changing circumstances that they face. In other words, each character is subtly shown to have some limited-perhaps instinctive, intuitive-sense of the dangers ahead. That none successfully acts upon it to avert disaster tends to compound the play's dominant tone of grim hopelessness.

Wardropper argues in relation to El pintor de su deshonra that 'it is only in the critical moments of dream, swoon, confidence, and turbación that [the unconscious life of the mind] stands revealed in its true nature'. 'In all these states of mind', he notes, 'the controls of reason are relaxed. The unconscious mind [...] is encouraged to take charge of the mental life.' In these circum-

\footnotetext{
${ }^{2}$ In Obras escogidas, ed. by Vicente de la Fuente, Biblioteca de Autores Españoles, 6o (Madrid: Rivadeneyra, 1868), pp. 177-234 (p. 177).

3 Bruce Wardropper, 'The Unconscious Mind in Calderón's El pintor de su deshonra', Hispanic Review, 18 (1950), 285-301 (p. 287). Wardropper argues that the spectator's sense of the injustice of Serafina's fate is attenuated by an understanding of her motives, hidden in her unconscious mind, and that her subliminal, unwilled desire for Álvaro can be glimpsed on several occasions, most notably in her fatal embrace of her former lover at the end of Act III, an impulsive action undertaken as Serafina wakes up, her mind still off guard.

4 Ibid., p. 289.
} 
stances man will 'loose his unconscious thoughts'. ${ }^{5}$ It is precisely in situations of the kind Wardropper lists that, in La cisma, the protagonists deploy the three allusions under discussion. Enrique has woken from a dream. Carlos is confiding in his criado. Catalina is turbada. But why should the mind act differently in such circumstances? This essay will argue that Calderón hints at the following explanation in La cisma: reason is impeded when a character is possessed by one or more of the passions, man's natural emotional (i.e. not rational per se) responses to (sometimes very troubling) sensitive apprehensions. These passions are the subject of Aquinas's treatise 'De passionibus animae' (questions 22-48 of the immensely influential Summa theologiae). ${ }^{6}$

In the wake of a dream Enrique is filled with sadness. Carlos too is said to be sorrowful as he pines for Ana. And Catalina is overcome with anger when she is slighted by Volseo. Tristitia and ira are passions carefully particularized in the Summa's 1azae and both are said to have the potential to impair reason. ${ }^{7}$ Calderón's three allusions, I think, hint that each of Enrique, Carlos, and Catalina is in possession of knowledge concerning the dangers they face, though only at a subliminal level. The knowledge has been acquired sensorily as normal (or, in Enrique's case, in a dream perhaps divinely inspired) but processed only cogitatively; the characters manage only an instinctive reaction in the form of their allusions. ${ }^{8}$ The passions and the knowledge that fires them do equip the characters to act to avert disaster; the passions are appetitive movements that should assist in willing good. But a passion can be utilized for the sake of good' only ' $[w]$ hen it is governed by reason'..$^{9}$ Enrique, Carlos, and Catalina fail properly to apprehend the dangers they face; they do not actualize the knowledge to which they have access, through the application of reason. This failing can be understood as resulting from the intense

\footnotetext{
5 Ibid., p. 287.

${ }^{6}$ Quotations from the Summa (original Latin and English translations, lightly modified) are taken from Thomas Aquinas, Summa theologiae, ed. by Thomas Gilby and others, 61 vols (Cambridge: Blackfriars, 1964-81; repr. Cambridge: Cambridge University Press, 2006).

7 The Summa states that 'ira, inter ceteras passiones, manifestius impedit iudicium rationis' (1a2ae 48, 3: 'Of all the emotions, anger more clearly prevents the judgement of reason'). It also describes 'immoderata tristitia, quae animum absorbet. huiusmodi enim tristitia immobilitat animum, et impedit fugam mali' (1a2ae 39, 3 ad $1 \mathrm{~m}$ 'uncontrolled sorrow, which devours the soul. For this kind of sorrow immobilizes the soul and prevents its escaping the malady').

8 The cogitative power (vis cogitativa) is the equivalent of that which in the higher non-human animals is called the estimative power (vis estimativa). It is this estimative power, which Aquinas refers to as a natural 'instinct' by which intensions are perceived $(1 \mathrm{a} 78,4)$, that is in operation when a lamb seeing 'a wolf approach flees, not because it does not like the colour or shape, but because it is its natural enemy'. The human power of cogitation is the same power as the animal estimative power (ibid., ad 5); it belongs, therefore, to a faculty which the human has in common with other animals, distinct from abstract reason. This subrational instinct could be the kind of thing that a seventeenth-century theatregoer might have understood to be prompting the characters' choices of allusion.

9 Robert Miner, Thomas Aquinas on the Passions (Cambridge: Cambridge University Press, 2009), p. 249.
} 
passions experienced. The overwhelming power of these passions could be compounded by sensory distraction and the need to act swiftly. It could be compounded too by deliberate inattentiveness, the repression of inconvenient truths that stand in the way of the satisfaction of desire. Either way, Enrique, Carlos, and Catalina fail to use reason to grasp the implications of the knowledge they have obtained, knowledge subtly revealed to the spectator through the ironic allusions. Calderón's engaged spectator will understand the characters' tragic failing: so often man possesses the knowledge necessary to make prudent moral decisions, but he fails to recognize it, hindered by his human limitations.

I do not mean to suggest that La cisma presents a sustained Thomist understanding of human psychology. I do not wish even to posit a direct Thomist influence; the play's depiction of human psychology is too circumscribed to be systematic or to engage meaningfully with philosophical controversies concerning the nature of human self-knowledge or cognition. Rather, my purpose in referring to Aquinas in these introductory comments is to demonstrate that, although the language and the precise concepts available to the Golden Age were not identical or even functionally equivalent to those of Freud or Jung, they nonetheless allowed for complexity and subtlety in the description of human mental processes, including notions of psychological self-opacity, as will be relevant to our analysis of the three allusions. In his monograph on 'De passionibus', Miner notes how Aquinas's approach to the passions 'anticipates, or is open to, many particular observations of empirical psychology'. ${ }^{10}$ Wardropper's use of the language of 'the unconscious mind' may seem anachronistic, but it does reflect the presence in Calderón's drama of men and women at times unable to comprehend the elusive movements of their minds. Such are the protagonists of La cisma.

\section{Queens Catalina and Esther}

Catalina's first appearance in La cisma is preceded by a number of scenes that provide context relevant to the episodes within which the three allusions are set. In a dream performed on stage, Enrique has a vision of an unknown woman, threatening but alluring. She appears to cause his left hand to erase the text he has written with his right hand, his orthodox defence of the sacrament of marriage, part of his anti-Lutheran Assertio septem sacramentorum. ${ }^{11}$ He is shaken by the dream and despite Volseo's attempts to reason with him, the king is left with a niggling sense of disquiet. The dream has evidently hit

10 Ibid., p. 189.

11 The irony of this dreamt action would be quite apparent to the spectator familiar with the record of Henry VIII's marriages. Irony-dramatic irony in particular-is especially pervasive in La cisma, and the three ironic allusions on which this article focuses fit into a complex skein of ironies. 
a raw nerve. His scholarly task appears to prompt him to recall the circumstances of his marriage to Catalina. She was first wed to his brother, Arturo, who died shortly after the wedding, before consummation. There is no doubt in Enrique's mind, he insists, that his subsequent marriage to Catalina was legitimate, and the papal dispensation valid. Enrique exits with the vision of an enticing but intimidating woman, and with the matters of the sanctity of marriage, and the legitimacy of his own, preying on his mind. In turn Volseo reveals to the audience the matters that prey perennially on his mind, namely, overweening ambition mixed with a latent sense of vulnerability as the social inferior of those with whom he fraternizes. Before he exits he remembers the horoscope cast at his birth: his ayo, he recalls, interpreted it as foretelling that 'una mujer | sería [su] destruición' (ll. 237-38). These early scenes lay the dramatic foundations for Catalina's allusion to Esther. (Note too how they involve a dream and a horoscope, both phenomena considered capable of influencing men in a manner not easily rationalized.)

Catalina enters at line 493 , to preside over the ceremonial welcome to the court of Ana Bolena, whom the audience will recognize as the femme fatale of Enrique's dream. Following Ana's bravura show of false humility and Catalina's kind but uneasy welcome of her nemesis, the queen's thoughts turn immediately to Enrique. The dramatic irony of the queen's train of thought is patent: the arrival of this woman, unfamiliar but evidently charming and ambitious, inspires Catalina immediately to look to her husband:

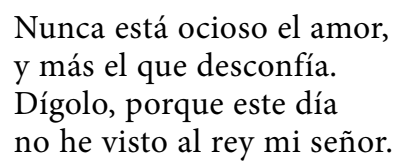

On the basis of the words exchanged thus far in this, her first scene, it is not at all apparent why Catalina feels this sudden sense of romantic vulnerability; the queen's desconfianza seems more intuitive than rational, perhaps the fruit of her subrational cogitative sense, which 'perceives harmfulness or beneficence' and impels the response the instinct directs as appropriate. ${ }^{12}$ Catalina moves decisively to reassure her amor, seeking Enrique out (" $[\mathrm{e}]$ ntrar en su cuarto intento | a saber de su salud' (1l. 643-44)). Volseo forbids her entry, though; the king is busy: '[e]n su aposento | está escribiendo, señora; | tu majestad no entre agora, | porque mandó que no entrase | persona que le estorbase' (ll. 647-51). In the light of the reasonably courteous tone of Volseo's words and the express fact that he is merely repeating the king's orders (given to Volseo at 1l. 209-11), the queen's reaction appears inordinately

12 Therese Scarpelli Cory, Aquinas on Human Self-Knowledge (Cambridge: Cambridge University Press, 2014), p. 10. 
haughty and gratuitously insulting. Catalina is in a state of turbación. Her sense of Ana's ambition and Volseo's perceived slight have provoked anger in her and her reason is clouded. (For Aquinas, interestingly, 'the sole motive of anger is slight or contempt', and anger leads the distracted reason 'to inflate the magnitude of wrong committed'. ${ }^{13}$ ) Neither Ana nor Volseo has, at this stage, obviously offered provocation sufficient to explain the fury of Catalina's response to being denied access to her husband. After angrily demanding of Volseo 'i[c]onocéisme?' (1.652) and upbraiding him for daring to stand in her way (ll. 656-58), the queen unleashes the following outburst containing the first of the three allusions to be analysed here, the allusion to Esther:

$$
\begin{aligned}
& \quad \text { ¡Loco, necio, vano! } \\
& \text { Por príncipe soberano } \\
& \text { de la Iglesia hoy os respeto; } \\
& \text { aquesa púrpura santa } \\
& \text { que por falso y lisonjero } \\
& \text { de hijo de un carnicero } \\
& \text { a los cielos os levanta, } \\
& \text { me turba, admira y espanta, } \\
& \text { para que deje de hacer... } \\
& \text { Pero bastará saber, } \\
& \text { ya que Amán os considero, } \\
& \text { que los preceptos de Asuero } \\
& \text { no se entienden con Ester. } \\
& \quad \text { (ll. 66o-72) }
\end{aligned}
$$

Catalina likens Volseo to Aman, the wicked chief minister of King Assuerus. By implication she designates Enrique as Assuerus himself. She places herself in the position of Queen Esther, quite logically, one might think. These analogies certainly make sense given their immediate context in La cisma, and the implied threat to Volseo would have been understood by Calderón's contemporaries, steeped as they were in biblical culture. ${ }^{14}$

The main action of the Book of Esther concerns the deliverance of the Jews of Assuerus's Persian Empire from the genocide planned by Aman and sanctioned by the luxurious king whom Aman manipulates. Esther, adoptive daughter of loyal Mardochai, is the saviour of the Jews. Because of her beauty, Assuerus picks her as his queen. But, it seems, even Esther is bound by the law prescribing death to anyone who enters into his presence without being

13 Miner, Thomas Aquinas on the Passions, pp. 280 and 274.

14 O'Reilly confirms the existence in sixteenth- and seventeenth-century Spain of a 'common biblical culture' in spite of the absence of a vernacular Bible. 'Writers and artists could take for granted at least a certain familiarity with biblical allusions, and, at best, a sensitive response to the biblical texts that informed their works' (Terence O'Reilly, The Bible in the Literary Imagination of the Spanish Golden Age (Philadelphia: Saint Joseph's University Press, 2010), p. 4). The Book of Esther provided the subject matter for a number of Golden Age comedias, including Lope de Vega's La hermosa Ester (1610) and La Reyna Ester (1613) by Felipe Godínez. 
summoned. To save her people Esther dares to break this law and the king pardons her, willing to move heaven and earth for this ravishing woman. After some time spent imbibing wine and Esther's lovely countenance, Assuerus grants her request that the Jews be shown mercy. The decree ordering their massacre cannot be revoked, but the king issues a new one permitting the Jews to defend themselves, which they do very successfully. Esther is then allowed one more favour, the overthrow and execution of Aman, who is hanged from the tall gibbet that he intended for Mardochai.

The overlap between the Book of Esther and the main action of La cisma is substantial, and it is easy to see why Catalina's current situation calls to her mind this famous story. The immediate prompt is Volseo's denying her the king's presence, which reminds her of Assuerus's ordinance, 'whosoever [...] cometh into the king's inner court, who is not called for, is immediately to be put to death without any delay: except the king shall hold out the golden sceptre to him, in token of clemency' (Esther 4. 11). ${ }^{15}$ Catalina recalls that Esther, because she pleased the king, was granted clemency when she entered the king's court unbidden (5. 2), and so she insists that, like Esther, she is exempt from the king's strictures: 'los preceptos de Asuero | no se entienden con Ester'. By drawing the analogy between Volseo and Aman she implicitly threatens the chancellor's life, unwittingly causing the chancellor to identify her as the woman of his horoscope, to her ultimate cost.

The modern editors of La cisma all confirm the Book of Esther as the text evoked by this allusion. Ruiz Ramón confirms the linking of Volseo and Aman, as does Escudero Baztán, who also includes a note describing the stricture referred to above. Mackenzie makes both points and adds that Esther successfully 'defied this law, in order to reveal Haman's iniquities to the King'. Finally, in his monograph on the play, Fernández Biggs summarizes all of these points. Escudero Baztán and Mackenzie both go a little further in exploring the allusion; they write, respectively:

El paralelismo entre Amán y Volseo resulta profético, pues como éste perderá el favor del rey y caerá en desgracia al final de la comedia.

Catherine's comparison, therefore, is a veiled but extremely powerful threat not only against Wolsey's high position but his life. The analogy is even more significant than Catherine yet realizes. For Queen Esther and her people were persecuted by Haman because they devotedly upheld their Jewish faith. And Wolsey will soon turn against Queen Catherine and oppose the authority of the Roman Catholic Church, which she devoutly recognizes. Eventually, however, like Haman, Wolsey will suffer the ruin which he deserves. ${ }^{16}$

\footnotetext{
15 Biblical quotations in Latin are taken from the Biblia Sacra iuxta Clementinam, ed. by Alberto Colunga and Laurentio Turrado (Madrid: B.A.C., 2005). English quotations come from the English translation of the Vulgate, the Holy Bible: Douay Version (London: Catholic Truth Society, 1956).

${ }^{16}$ See Calderón de la Barca, La cisma de Inglaterra, ed. by Francisco Ruiz Ramón, Clásicos
} 
Both are correct in their suggestion that the allusion is vatic. The spectator familiar with the Esther story and with Henry VIII's reign, however, might retain certain scruples. Calderón relies on these to lead the spectator to identify the flaw in Catalina's analogy, a flaw that casts into relief the instinctive fears stirring tantalizingly in her mind. Yes, like Aman, Wolsey was cast down by Henry. Yes, this was the result of the queen's intervention. And yes, because of the king's indulgence of his queen her co-religionists prospered in England as the Jews did in Persia. But, as the informed spectator would have known, neither feat was achieved by the historical Katherine of Aragon, and neither is achieved by Calderón's Catalina. Both are achieved, however, by Ana Bolena, as they were by Anne. She is the new Esther. Catalina is not Esther but Vasthi, Assuerus's first queen, cast aside before his marriage to the Hebrew heroine.

Queen Vasthi is Assuerus's wife at the start of the biblical story. She is a much closer match for Catalina. In her modesty, Vasthi arranges a separate feast for women while the king feasts with the men in Esther 1. Disregarding her modesty and 'well warmed with wine' (1.10), this lascivious king commands that Vasthi present herself before the drunken men, 'to shew her beauty to all the people' (1.11). Considering the command an illegitimate affront Vasthi declines to comply and, as a result, following advice from his counsellors, Assuerus's first queen is deposed, to be replaced by the enchanting Esther. The parallels with Catalina's plight are clear. At the end of Act II of La cisma she will be deposed following advice from Volseo, who will urge Enrique, '[s]al del yugo, sacude la obediencia, | repudia a Catalina' (1l. 1586-87). Catalina will oppose the king's will, believing it to be sinful and dangerous, in principled defence of Catholic orthodoxy (ll. 1792-1893). And she will be replaced by the seductive Ana as Enrique's consort.

The parallels between Catalina and Vasthi extend beyond these well-known details of both queens' biographies. After he has ordered Ana's execution late in Act III, for instance, Calderón's Enrique remembers Catalina and regrets his mistreatment of her. Apparently inspired by God, he demands that she be restored to court:

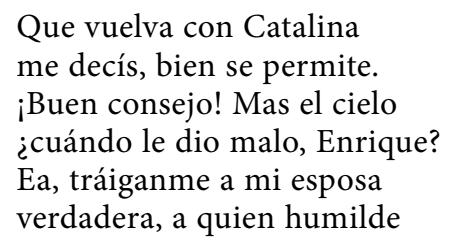

Castalia, 119 (Madrid: Castalia, 1981), p. 101; La cisma, ed. by Escudero Baztán, p. 152; B. Fernández Biggs, Calderón y Shakespeare: los personajes en 'La cisma de Ingalaterra' y 'Henry VIII' (Madrid: Iberoamericana; Frankfurt a.M.: Vervuert, 2012), p. 215; and Ann L. Mackenzie (ed.), The Schism in England/La cisma de Inglaterra, trans. by Kenneth Muir and Ann L. Mackenzie (Warminster: Aris \& Phillips, 1990), p. 207. 
pediré que pida a Dios

que con su piedad me mire.

(11. 2656-63)

While Assuerus does not expressly call for Vasthi's return, he does 'remember' her affectionately: '[a]fter this, when the wrath of king Assuerus was appeased, he remembered Vasthi, and what she had done and what she had suffered' (2.1). Assuerus's repudiation of Vasthi cannot be revoked, however; his commands are irrevocable, '[f] or this was the custom, that no man durst gainsay the letters which were sent in the king's name' (8. 8). Similarly, Enrique's repudiation of Catalina cannot be revoked, despite his willing it so. His unhistorical change of heart coincides with her death (11. 2671-76): 'es ya | restitución imposible', 'ipues ya quiero arrepentirme! | Pero es muy tarde, no puedo' (11. 2692-93 and 2703-04).

Unlike Catalina, whom Enrique does not exempt from his request for solitude, Ana Bolena is granted the king's favour from the moment he signals his indulgence with the command '[a]lzad, no estéis en el suelo' (1. 871). (Perhaps a sensitive director would have had Enrique hold out his golden sceptre at this point.) Ana it is who orchestrates Volseo's overthrow, confessing to Enrique that she has been scorned by the chancellor. In words that bear a faint echo of Assuerus's enraged response to Esther's revelation that she and the Jewish people are beset by an enemy-' [q]uis est iste, et cuius potentiae, ut haec audeat facere?' ( 7.5 'Who is this, and of what power, that he should do these things?')-Enrique demands to know from Ana 'i[q]uién fue | quien a ti te pudo dar | ocasión?' (1l. 2174-76). Esther names Aman. Ana names Volseo. Both men are immediately stripped of their powers and deprived of their property (7.10 and 8. 1, and 11. 2231-37 respectively). The actions of Esther-who initially hides her religion from the king-ensure the safety of the Jews. Catalina and her daughter, Mary, both zealous Catholic apologists, are ultimately unable to defend Catholicism in England, a fact notorious in Spain by the time La cisma was first performed, probably around 1627. Ana, on the other hand, who, like Esther, hides her religious convictions initially (she is 'en secreto luterana' (1. 456)), brought Protestants into the inner sanctums of royal power for the first time, and her daughter, Elizabeth, cemented the break with Rome. Calderón has Ana's 'father', Tomás Boleno, promoted to the Presidencia del Reino at Volseo's expense (1l. 2083-84), just as Esther's 'father', Mardochai, replaces Aman as the king's chief minister (8. 2). Interestingly, finally, Esther is not Mardochai's natural daughter but his adoptive daughter (2. 7). In this too Ana Bolena is a neat fit with Esther, but I shall defer discussion of this aspect of the analogy to my analysis of the third allusion, by which Carlos compares Ana to Juno's peacock.

The engaged spectator will understand, then, that Catalina's self- 
identification with Esther is misconceived. The following objections might be raised to the drawing of an analogy with Vasthi, however. First, that it is perverse to cast Calderón's heroine as a woman described by one biblical exegete as an 'insolent' queen rightfully deposed. Second, that the knowledge being expected of the spectator is so abstruse that the irony of the allusion would be lost; as Pasco observes in his book on intertextuality, '[a]llusion that is not recognized does not function'. ${ }^{17}$ Both objections can be dismissed.

In Golden Age Spain disapproval of Vasthi was associated with Martin Luther, according to the Capuchin friar Leandro de Murcia, author of an extensive exegesis of Esther. An alternative reading of Esther, evidently considered the orthodox one by Murcia, casts Vasthi in a different light, a more flattering tradition that stretches back to Josephus and presents her, in the words of another modern exegete (who is describing the breadth of responses to this queen), as 'the only admirable person' in that Old Testament story, a queen 'who upheld morality in defiance of a drunken, lascivious king.' ${ }^{18}$ It makes good sense, then, to link the heroine Catalina to Vasthi in the light of this exegetical tradition. And the point is not obscure. There are a variety of witnesses from Golden Age Spain.

In his Commentaria in librum Esther (Madrid, 1648) Murcia begins his answer to the question 'An legitime \& iuste [...] fuerit repudiata Vasthi Regina, a Rege Assuero' ('Whether Queen Vasthi was repudiated legitimately and justly by King Assuerus') by expressly identifying negative estimations of Vasthi with Luther and Johannes Brenz. He comments disapprovingly how, justifying their stance on divorce, 'Lutterus [\& Brentius] [. . .] approbant factum Assueri, Reginamque Vasthi arrogantiae, \& contumatiae accusant' ('Luther and Brenz approve of Assuerus's action and accuse Queen Vasthi of arrogance and contumacy'). ${ }^{19}$ Citing a host of orthodox authorities, Murcia insists on the righteousness of Vasthi's actions. These authorities

asserunt Reginam ad convivium ab Assuero vocatam, ex iustissima causa venire renuisse, \& ideo iniustissime a Rege ob eandem causam fuisse repudiatam; septemque sapientes, qui Regi Assuero assistebant, iniquam in ipsam tulisse sententiam, pravumque, \& iniustum consilium de Reginae repudio eidem Regi praebuisse.

assert that the queen, having been invited to the banquet by Assuerus, with complete justification refused to come, and was therefore most unjustly divorced by the king for that very reason; and the seven counsellors who served King Assuerus delivered

17 See, respectively: Marco Conti and Gianluca Pilara (eds), Ancient Christian Commentary on Scripture: Old Testament, v: 1-2 Kings, 1-2 Chronicles, Ezra, Nehemiah, Esther (Downers Grove, IL: InterVarsity Press, 2008), p. 377; and Allan H. Pasco, Allusion: A Literary Graft (Toronto: University of Toronto Press, 1994), p. 18.

18 Carey A. Moore, Esther, The Anchor Yale Bible (New Haven \& London: Yale University Press, 2011), p. 13.

19 Leandro de Murcia, Commentaria ad litteram et moralia in librum Esther (Madrid: Ildephonsi a Paredes, 1648), p. 94. 
an unfair judgement against her, and also submitted to the king a perverse and unjust opinion on his divorce from the queen.

Murcia explains further that Vasthi's decision resulted from her praiseworthy desire to respect the law that prohibited wives from allowing themselves to be seen by strangers. Her behaviour was entirely virtuous, a note struck loud and often in the relevant section of the Commentaria. ${ }^{20}$

Of course, relatively few seventeenth-century spectators would have known Murcia's exegesis or others like it directly (though, surely, many would have heard his and similar views in the sermons that formed an everyday part of life in seventeenth-century Spain, the Council of Trent having promoted a 'renewal of biblical preaching'). ${ }^{21}$ The same positive reading of Vasthi can be found, however, in more popular works of devotional literature in Castilian, such as Malón de Chaide's famous Libro de la conversión de la Magdalena (1588). There Malón comments that, in response to the king's request that Vasthi present herself as 'el último plato que se había de servir a los convidados':

la reina anduvo harto más discreta en no ir que el rey en mandarla llamar, porque para la gravedad y honestidad de tan gran señora, no le decía bien el ir a una huerta a ser terrero de los ojos de tantos hombres y criados suyos. Al fin determinó no cumplir en esto la voluntad del rey, de lo que quedó sentidísimo y estomagado contra la pobre de la reina. ${ }^{22}$

So, Calderón's audiences would have known the story of Esther and Vasthi and many among them would have known to feel sympathy for the deposed queen. I suspect, then, that the more engaged and learned spectators, by comparing the Esther story with the life of Katherine of Aragon, would have identified Catalina's error in pointing to Esther as her precursor. The subtext opened up by the disparity between the cases of Katherine and Esther would, I think, have prompted many to consider what Catalina's choice of allusion might reveal about her character. ${ }^{23}$ A number of distinct conclusions could be drawn.

First, a spectator might decide that Catalina has no concerns about the

${ }^{20}$ Ibid., pp. 94-95.

21 O'Reilly, The Bible in the Literary Imagination of the Spanish Golden Age, p. 218.

${ }_{22}$ Malón de Chaide, Libro de la conversión de la Magdalena (Madrid: Pedro Madrigal, 1598), fol. $78^{\mathrm{r}}$.

23 Allan Pasco writes interestingly that 'allusion is more than the external term or intertext, indeed, more than the sum of the internal and external terms. It is a relationship between a minimum of two terms that, through varying degrees of parallels or oppositions, creates a new entity greater than any of its constituent parts' (Allusion, pp. 13-14). Our current allusion incorporates at least three source 'texts' (though it may be that a precise text is not involved in every case, but rather widely disseminated cultural knowledge), namely the Bible, the history of Henry VIII's Great Matter, and Calderón's play. I shall now proceed to discuss the greater 'entity' to which the interplay between these diverse texts gives rise. 
security of her position, choosing to link herself with Esther because she considers herself invulnerable. Such self-assuredness might explain the haughtiness of her words to Volseo, but it would sit uncomfortably with the implied admission that her amor is one 'que desconfía'. If one supposes, on the other hand, that Catalina is quite aware of her vulnerability and of the challenge Ana and Volseo are about to mount to her position, then her self-identification with Esther can be interpreted as a defiant attempt to assert the permanence of her place in the king's heart and of her concomitant political power. Ignoring or forgetting, in the heat of the moment, the existence of Assuerus's first wife, Catalina, reminded of the Esther story when denied access to the king, latches onto Esther as the paradigm of a queen denied nothing by her king, an influential queen able to procure the overthrow of even the most insidious enemy. Catalina could be striking a pose, then, hiding her desconfianza in an attempt to stare down her antagonists. In this case, the spectator could still detect irony in the allusion to Esther, could still pity Catalina for her failure to foresee the gravity of her predicament. This is perhaps a difficult interpretation to sustain, however, since Catalina publicly, though indirectly, admits her desconfianza. And I would question what, in the play's action up to the Esther allusion, could have led the queen to have such a clear sense of her vulnerability. She knows nothing of Enrique's dream and must still consider him committed to their marriage. Similarly, she knows nothing of Ana's impending bid for power; the spectator knows of the scale of Ana's 'vanidad' and 'ambición' (1. 450) thanks only to a private dialogue between Carlos and Dionís (1l. 305-464). Catalina has, though, just enough evidence to prompt an observant, intuitive person to begin to sense that something might be afoot.

Briefly, the evidence is the following. The deference Ana shows to Catalina is so hyperbolic as to suggest insincerity, and it allows Catalina to glimpse her ambition. Ana describes her breath as 'ufano' (1. 497) and suggests it is rising up to the moon, the secondary sphere by which Ana designates Catalina. Most disquietingly, but ambivalently, Ana admits that 'tanto levantarme espero | que en el sol me considero' (ll. 636-37). Catalina senses Ana's ambition and chides her for striking an attitude appropriate only for God: 'que esas ceremonias son | de quien con vana ambición | a lo divino se atreve' (1l. 518-20). Next, there is the cryptic prophecy of the gracioso, Pasquín, who says to Ana, 'muy hermosa y muy ufana | venís a palacio' (1l. 620-21), and suspects she will be loved 'hasta poderos alzar $\mid$ con todo el imperio inglés' (1l. 629-30). Then there is a disconcerting note struck by the unusual tense choice in Volseo's words to Catalina. In reply to her outraged present tense '¿ $[\mathrm{c}]$ onocéisme?', Volseo asks ‘[q]uién ignora| que vos mi reina habéis sido?' (ll. 652-53, emphasis added). Finally, Catalina's mind might be disturbed by the denial of her husband's 
presence. As I read this scene, Catalina does pick up on these signals. They lead her to feel desconfianza and to think instinctively of her husband, faced with the beautiful, ambitious Ana. They also incite anger in her. The power of this passion impairs her reason. Her cogitative power has suggested to her, instinctively, the story of Esther, containing within it a clear precedent for her situation, but one that, tragically, isolated and flustered, Catalina fails to apprehend. It is not Catalina but Ana Bolena who will, albeit briefly, don Esther's crown. The failure of Catalina's reason to process the implications of the allusion that has occurred to her deprives her of the chance to evade disaster. Instead she hastens its coming by making an enemy of Volseo, in whose mouth Calderón puts (rather insistent) confirmation of the queen's dominant passion, ira. She has shown herself 'sólo airada para mí' (l. 686), a 'reina airada' (1.697) who 'es enojada, terrible' (1. 688). Calderón makes it equally apparent in the case of Enrique that the dominant passion he feels in the wake of his disturbing dream is Aquinas's tristitia: the king laments 'i[q]ué tristeza!' (1. 167) as he suffers the dream's effects and, at the end of the speech in which he compares himself to Mars, he declares '[t] riste estoy' (1. 212). ${ }^{24}$

\section{Enrique and Mars}

Like Catalina, Enrique deploys his allusion while in a state of turbación, having just awoken from his dream, sleep being a state in which reason is necessarily impeded (Summa, 1a2ae, 49, 3). Whereas, fittingly for a famously pious woman, Catalina's allusion is biblical, 'heretic' Enrique resorts to pagan mythology. The symbolism of Enrique's dream (detailed above) should be clear to anyone with even rudimentary knowledge only of Henry's reign. The spectator must anticipate that, as occurred historically, by the end of the comedia Enrique will have set Catalina aside and entered into a bigamous, adulterous marriage with Ana, simultaneously severing England's communion with Rome. Again, though, Calderón's Enrique cannot know what lies ahead; when he links himself to Mars he has never met Ana and he is a fierce defender of Catholicism. His allusion to Mars allows the spectator to espy the desires and fears lurking in his mind, stirred by his dream, but obscured by the overwhelming tristitia he feels as an intuitive response to the dream's content.

Having reminded Volseo of the circumstances of his marriage to his brother's virgin widow, including the grant of a papal dispensation (to waive the breach of the canon law of affinity), Enrique remembers, in his first lengthy speech in La cisma, the active steps that in writing his Assertio he is taking in defence of la fe:

\footnotetext{
${ }^{24}$ In fact sorrow remains with Enrique throughout the first half of the play. Within the first twenty-five lines of Act II, for instance, Enrique is described as 'triste' three times (1l. 925, 929, and 933).
} 
y para decir también, cardenal, de la manera que la defiendo, asistiendo con el ingenio y las fuerzas; pues ahora que Marte duerme sobre las armas sangrientas, velo yo sobre los libros, escribiendo en la defensa de los siete sacramentos [...] (1l. $73-81)$

The obvious reason why Enrique's mind might suggest to him the evocation of Mars is identified by the play's modern editors. ${ }^{25}$ Enrique wishes to evoke the idea that, since England is enjoying a period of peace-the god of war is sleeping - he is serving his people by writing in defence of religion. He is the Renaissance ideal of the soldier scholar. Hearing tell of 'Marte du[rmiendo] | sobre las armas sangrientas', the Golden Age spectator might well have imagined the god's lassitude to result from his physical exertions on some duro campo di battaglia. The ubiquity in the Golden Age of both the metaphorical associations of war (prominent above all in the Petrarchan tradition) and pictorial images of the sleeping Mars, however, might have led Calderón's spectators to understand Enrique's allusion to reveal his desire for adulterous sex. When the cultured seventeenth-century Spaniard thought of Mars sleeping beside a pile of armour, he would see in his mind's eye the god of war either locked in an adulterous embrace with Vulcan's wife, Venus, or resting beside her, in an attitude of post-coital lethargy.

The tale of Mars's adultery with Venus was exploited on very many occasions by the poets and artists of early modern Europe, not least in Golden Age Spain. It was, consequently, very well known. Although some of the tale's peripheral details vary between its principal classical tellings, these sourcesHomer, Ovid, Lucian, and Reposianus-agree on the essential core of the anecdote. ${ }^{26}$ Since, according to Torres, Ovid's Metamorphoses 'occupies an unchallenged position as the major source of all mythological material in the

\footnotetext{
25 Escudero Baztán quotes from Pérez de Moya's Philosofía secreta to remind his readers of Mars's identity (La cisma, p. 126). Mackenzie makes the same point, but suggests too that the allusion evokes a chivalric tradition: 'Calderón smartens up a worn illusion [sic], to emphasize Henry's scholarly commitment to the Faith. A king traditionally keeps watch over his arms before battle. In this case, however, Mars, the Warrior-God, sleeps upon his weapons, exhausted, it seems, after the bloodshed of conflict. England is enjoying a period of peace. But Henry holds vigil, among his books, preparing a written defence of the Church of Rome against the violent onslaught of Luther's published heresies' (The Schism, pp. 195-96).

${ }^{26}$ See Oliver Noble Wood, A Tale Blazed through Heaven: Imitation and Invention in the Golden Age of Spain (Oxford: Oxford University Press, 2014), ch. 1, for a precise and very readable overview of these sources.
} 
Middle Ages and the Renaissance', let us base our summary of the tale on that concise version (IV. 169-89). ${ }^{27}$

Apollo, god of the sun, catches sight of Mars and Venus in flagrante delicto. Shocked, he rushes to Venus's husband, Vulcan, and describes the scene he has witnessed. Vulcan forges a net of fine bronze links. He spreads it over the bed where the lovers committed their sin of adultery, and when they return there to sin again the trap is sprung and they are caught in the net, whereupon Vulcan invites the other gods to gaze upon the spectacle.

Enrique's reference to Mars is fleeting, merely a pair of octosyllables. Venus, Vulcan, and Apollo go unnamed. There is no explicit reference to adultery or to nets. I strongly suspect, notwithstanding, that the information Calderón provides is amply sufficient immediately to conjure up in the cultured spectator's mind this classical myth. If merely naming Mars does not prompt one to call to mind his adultery with Venus, surely the description of a Mars who 'duerme | sobre las armas sangrientas' does. Mars's weapons are an almost constant feature of pictorial representations of this episode. They are clearly visible, usually beside the bed, in fourteen illustrations of the tale (of the fifteen in which Mars appears) reproduced in Noble Wood's study of it, for instance. The arms are typically shown in a heap, dropped beside the bed in their owner's haste to jump into it. ${ }^{28}$ And while Mars is literally asleep in a minority only of these illustrations (for example, in Botticelli's Venus and Mars (c. 1485) and in Piero di Cosimo's Venus, Mars, and Cupid (1490)), surely Calderón's 'duerme' can be taken as a euphemism, necessary in La cisma to preserve the allusion's subtle ironic effect.

In seventeenth-century Spain, knowledge of the tale of Mars and Venus was widespread. If it seems arcane today, it was not then. The better-educated men would have become familiar with it as part of their schooling, provided by the Jesuits in many cases. Calderón himself was educated at the Jesuit college in Madrid's Calle de Toledo, whose curriculum had at its heart the classical languages and literatures, especially Latin. ${ }^{29}$ Knowledge of classical mytho-

\footnotetext{
27 Isabel Torres, 'Introduction: Con pretensión de Fénix', in Rewriting Classical Mythology in the Hispanic Baroque, ed. by Isabel Torres (Woodbridge: Tamesis, 2007), pp. 1-16 (p. 7).

${ }^{28}$ Mars's arms are not visibly bloodied in the best-known iconographical depictions of the tale. In line 77 of Reposianus's 'De concubitu Martis et Veneris', though, Mars is said to come to Venus from war: 'ecce furens post bella deus' ('behold in frenzy after warfare comes the god'), which could explain the description of the arms as sangrientas (Minor Latin Poets, trans. by J. Wight Duff and Arnold M. Duff, Loeb Classical Library, 434 (Cambridge, MA: Harvard University Press, 1934), pp. 530-31). This detail might be included by Calderón to emphasize Enrique's sense of his own potency. It might point forward to the bloody fate of Ana Bolena. It could, alternatively, simply be that Calderón is using a 'stock epithet'. Noble Wood confirms that sangriento is one of the stock epithets 'often adduced' in conjunction with the figure of Mars (A Tale Blazed through Heaven, p. 51).

29 Don Cruickshank, Don Pedro Calderón (Cambridge: Cambridge University Press, 2009), p. 33 .
} 
logy acquired in childhood would have been kept alive by acquaintance with all kinds of contemporary cultural outputs: poetry, prose, drama, painting, and sculpture were all art forms that relied heavily on classical mythology for their cultural referents. And the adulterous affair between Mars and Venus is not a minor footnote to their tales. On the contrary, it is one of their most prominent details, writ large in the major mythographic works of the period. Take, for instance, the 'highly popular mythographic manual' that facilitated 'myth's explosion onto the vernacular scene' in sixteenth-century Spain, Pérez de Moya's Philosofía secreta (1585)..$^{30}$ The very first paragraph of the chapter on Mars ('De Marte', chapter XXvi of book 2) mentions the episode to which Calderón's Enrique unwittingly alludes: 'entre otras amigas [Marte] amó a Venus [. . .] a quien Vulcano prendió hallándole en adulterio'; further details follow. ${ }^{31}$ The affair provides the subject matter for a whole chapter of Baltasar de Vitoria's Teatro de los dioses de la gentilidad (pt I, 1620; pt II, 1623), 'De los amores del dios Marte y Venus' (pt I, book 6). ${ }^{32}$ And likewise Jean Tixier de Ravisi's Epitheta includes in its bite-size summary of the Mars myth the detail that the god was in adulterio cum Venere deprehensum, catenis ligatum a Vulcano' ('caught in adultery with Venus, bound by Vulcan in chains'). ${ }^{33}$ Reasonably cultured spectators of La cisma, then, were likely to think of this episode when Enrique describes Mars sleeping beside his weapons, and they would understand that Enrique has adulterous sex on his mind, prompted by his dream.

How much further can the spectator go in teasing out the relevance of the Mars analogy to the case of Calderón's Enrique, using his historical knowledge of Henry VIII as a guide? The matter is a difficult one because the figures of Mars, Venus, and Vulcan could be linked to the play's characters according to several permutations. Venus could represent Catalina, in which case one could understand Enrique to be revealing a deep-seated anxiety that in marrying his brother's widow he is a Mars illegitimately enjoying carnal relations with another (older) man's wife. This fit is not a good one, however. Following Arturo's death, Enrique's relationship with Catalina would not have been thought adulterous but rather incestuous. And besides, by the time of his encounter with Anne Boleyn, the historical Henry had long tired of the saintly Katherine as his bedfellow. Once again, it makes better sense to place Ana Bolena at the heart of the allusion, in the role of Venus, goddess of love. Though at this point in the play Enrique has not met Ana, he has dreamt of

30 Torres, 'Introduction: Con pretensión de Fénix', p. 8.

31 Juan Pérez de Moya, Philosofía secreta de la gentilidad, ed. by Carlos Clavería, Letras Hispánicas, 404 (Madrid: Cátedra, 1995), p. 289.

${ }^{22}$ Baltasar de Vitoria, Teatro de los dioses de la gentilidad, pt I (Salamanca: Antonia Ramírez, 1620), pp. $894 \mathrm{ff}$.

33 Jo. Ravisii Textoris, Nivernensis, poetae celeberrimi epithetorum opus perfectissimum, ed. by Johannes Jacobus Grasserus [Johann Jakob Grasser] (Basel: Conrad Waldkirch, 1612), p. 510. 
her and been struck by her beauty ('sombra divina, imagen bella' (1. 1)). His choice of allusion suggests that he would rather like to find himself in bed with this woman who is not his wife. This may be as far as the spectator can take the allusion at this stage, because thus far, no obvious Vulcan analogue has appeared. Such a figure will be introduced shortly after Enrique's opening scene, however, and the role he plays in La cisma will demonstrate once again the vatic irony of Calderón's allusions.

So, whose wife is Ana-Venus? Well, Carlos, the French ambassador, claims to be her esposo and suggests periphrastically to Dionís that he has already enjoyed her sexually ('gocé, tuve, alcancé dulces favores' (1. 385) etc.). ${ }^{34}$ In the light of this, the spectator might-assuming he is still pondering the Mars allusion-link Carlos with Vulcan and take Enrique's incipient relationship with Ana as an adulterous one because she (as well as he) is already betrothed. Once again, however, the spectator might retain certain productive scruples. If Ana makes a fitting Venus and Enrique a passable Mars, does Carlos strike one as a lame old cuckold like Vulcan? Does Carlos, like Vulcan, catch Enrique and Ana in flagrante and does he punish them for their sin? No. Enrique might, of course, like to think of himself as Mars, but, as the action of La cisma develops, the spectator should conclude that, just as Catalina was misguided in casting herself as Esther, failing to note how she resembles Vasthi, Enrique's self-identification with the god of war is misconceived, wishful thinking. As many a well-informed spectator would have known, historically, Henry claimed to have been cuckolded by Anne Boleyn, many times over. ${ }^{35}$ Calderón's ageing Enrique, personally and politically humiliated by the end of the play, is the better analogue for Vulcan, and the playwright's desire to cement that reading can explain, in part, the scene between 11. 2466 and 2535, which has no precedent in Calderón's source. There, Enrique, hiding behind the arras, catches Ana and Carlos confirming their past romantic attachment and the former elusively suggesting that it might, in the near future, be re-formed. Like Vulcan, it is Enrique who chooses to avenge himself by punishing the young lovers: Ana and Carlos are sent to the Tower of London following the king's discovery of their intimacy (1l. 2566-72). Ana is executed and we assume Carlos is too (though we are not told).

I do not mean to suggest that all of this is present in detail in Enrique's mind: merely that the seeds of this tragedy have begun to germinate there, a consequence of the dream that stoked the flames of a latent discontentment

\footnotetext{
34 Initially Carlos confesses himself content to have Ana as his mistress, but later he changes his mind, offering her his mano de esposo (1. 825). Later he returns from France to England for his 'casamiento' (1. 1991) and asserts his prior 'ownership' of Ana, who has married the king in his absence: '[e]n mi ausencia triste | me quitó lo que era mío’ (ll. 2483-84).

35 Historians who have written in recent decades about Anne's trial tend to argue that much evidence actually points to her having been innocent of the charges of adultery.
} 
with his modest, chaste wife and a desire for a younger bedfellow. For while Enrique was captivated by the phantasm's loveliness, he was simultaneously dubious of her, describing her enigmatically as a 'sol eclipsado', a 'deslucida estrella' (1. 2). The contrasting implications of the two interpretations of the Mars allusion set out above hint at the mystery that is Ana Bolena at the start of La cisma. The cogitative power of Enrique's mind instinctively anticipates that such a woman could play a Venus to his Mars, but, simultaneously, it fears that she could swiftly turn the tables on him, casting him as the frustrated cuckold, Vulcan. Had he retained control of his reason, Enrique might have teased out some ominous implications from the allusion that occurred to his mind. But he was overcome by an intuitive sorrow. As per Aquinas, 'omnes passiones animae regulari debent secundum regulam rationis, quae est radix boni honesti. quam transcendit immoderata tristitia [. . .]. et ideo recedit a ratione honesti' (39, 2 ad $1 \mathrm{~m}$ : 'All the passions of the soul must be regulated according to the rule of reason, which is the root of moral goodness. Uncontrolled sorrow [...] transgresses that rule, and therefore falls short of moral reasoning').

It is possible that Calderón intended nothing beyond conventional dramatic irony with this allusion, to hint, simply, that Enrique desires an extramarital sexual encounter. Evidence in La cisma beyond these allusions leads me to suspect, though, that Calderón intended, rather, that the spectator also consider the workings of his characters' minds. At the moment when he names Mars, Enrique is shown to experience feelings that his reason fails to comprehend.

Ruiz Ramón has written persuasively on this evidence. As Enrique recounts his dream to Volseo, he evidently senses that there is some, at this stage elusive, significance to the doctrinal argument in which he saw himself engaged at the moment of the Ana-phantasm's appearance: '[e]scribiendo estaba, pues, | (en el sacramento era | del matrimonio, jay de mí!)’ (1l. 97-99). His exclamation indicates that he is troubled by this detail. The spectator understands its ominous implications, but at this stage Enrique does not, although he is distressed by it in the intuitive way one often can be upon waking from a bad dream. For Ruiz Ramón, this simple but moving '¡ay de mí!' is effective in revealing the king's subliminal fears. It is an 'índice, escueto, pero significativo, de los inconfesados temores del rey'. ${ }^{36}$ These fears leave him feeling melancholy'[t]riste estoy' (1. 212), '[t]riste está el rey' (1. 925)-but incapable, I think because of his sadness, which 'immobilitat animum' (Summa, 39, 3 ad 1m), of understanding fully the basis for his fears. The king's dream does not give rise to his desire for a younger lover or to his willingness to overturn Catholic orthodoxy to secure his pleasure. Both impulses are shown by Calderón to be already latent in the king's mind: they pre-exist and inform the dream, as they

${ }^{36}$ La cisma, p. 11. 
inform Enrique's allusion. This is the significance that Ruiz Ramón attributes to Enrique's description of the workings of his own dream. The 'sombras del sueño | imágenes dio a la idea' (ll. 95-96), Enrique explains. The 'imágenes' of the dream give form to an 'idea' which must, logically, have pre-existed it and of which the king must, at some level, have been aware before he dreamt. ${ }^{37} \mathrm{By}$ the end of Act I, the king's desire will grow beyond subliminal stirrings. He will be painfully aware of his passion for Ana and his boredom with Catalina. As his desire for Ana leads him to act, however, the king's initial wariness of the woman of his dream-a wariness reinforced by his ironic Mars allusionis forgotten, to his cost. He fails to question whether he truly is the Mars with whom he self-identifies.

The final allusion to be analysed also hints at Ana's elusive character. I shall argue that it allows Calderón to suggest to his audience indirectly aspects of the historical Anne's person (treated expressly in Rivadeneira) that critics of La cisma have claimed the playwright passes over in silence in the interests of decorum.

\section{Ana Bolena and Juno's Peacock}

When Carlos recounts to Dionís the story of his relations with Ana, he is confiding in his criado; this is one of the scenarios that, Wardropper argues, Calderón uses when he wishes to allow us to glimpse his characters' unconscious minds. Moreover, Carlos is, like Enrique, said to appear 'triste' (1. 305). At the thought of leaving England, Dionís comments to his master, 'te entristeces' (1. 326). Despite Carlos's evident enthusiasm for Ana's charms, he is simultaneously aware of unattractive facets of her character. He describes her as 'veneno' (1. 338) and a 'bellísima sirena' (1.346), enchanting yet dangerous. He continues:

$$
\begin{aligned}
& \text { Vila en París un día. ¡A Dios pluguiera } \\
& \text { no que (como se dice) antes cegara, } \\
& \text { sino que a tantas plumas rayos diera, } \\
& \text { que al ave más hermosa así imitara! } \\
& \text { Fuera el pavón de Juno entonces [...] } \\
& \text { (1l. } 349-53)
\end{aligned}
$$

The superficial gist of the evocation of Juno's peacock is to emphasize Ana's beauty; in propitious circumstances (more light) she would rival this, ${ }^{38}$ the loveliest of birds, traditionally linked to the Roman goddess of marriage. The peacock concurrently evokes certain negative associations. In his edition of

37 Ibid., p. 10.

38 Pliny the Elder records the belief that 'when praised, [the peacock] spreads out its feathers to face the sun, so they shine more brilliantly' (Historia naturalis, x. 22-23). 
the play Ruiz Ramón identifies these as vanity and pride and suggests that it symbolizes 'la mujer hermosa y gallarda que se precia de serlo', an apt description of Ana. ${ }^{39}$ These points are reiterated by Mackenzie (who also mentions the influence of Góngora's Soledad primera (1l. 806-08) on Calderón's description of the peacock). Most interestingly, though, Escudero's note focuses on Juno's genealogy, though it does not comment upon the subtext this introduces. Quoting Pérez de Moya, Escudero Baztán explains that Juno was born 'de un mismo parto con Júpiter' and that Jupiter, 'enamorado de la belleza de su hermana se convirtió en cuquillo para gozarla y casarse con ella'. ${ }^{40}$ This scandalous detail of the Juno myth was extremely well known. In fact, in Pérez's Philosofía the very title of the pertinent section is 'De Juno, hermana y mujer de Júpiter'. ${ }^{11}$ Juno's marriage to Jupiter was incestuous.

The incestuous nature of this relationship is referred to in several of the works best known to Spain's Golden Age. Virgil's Aeneid describes Juno as 'Iovisque et soror et coniunx' (I. 46-47: 'at once sister and wife of Jupiter'). Ovid refers to her likewise as 'sociae generisque torique' (I. 620: 'united to him in birth and in wedlock'). And alongside the Philosofía secreta stands Vitoria's Teatro, which confirms that Jupiter 'se casó con su hermana Juno'. ${ }^{42}$ So, as before, even with a small amount of classical learning, the Golden Age spectator could understand more from Carlos's allusion than the beauty and arrogance the Frenchman obviously intends to suggest. Were Carlos convinced of the most scandalous details of Ana's life he would surely not conceive of pursuing her.

The spectator knows that Carlos has doubts concerning Ana that incline him, initially, against marriage to her: '[y]o, enamorado y dudoso | de condición semejante, | quisiera gozarla amante | antes que llorarla esposo' (1l. 4576o). The doubts are said to be founded upon his awareness that Ana is haughty, vain, and ambitious and that she is a secret Lutheran, he suspects (1l. 449-56). But his allusion to Juno might hint at his unspoken knowledge of rumours concerning her illegitimacy and sexual impurity, rumours he might dearly wish to ignore. ${ }^{43}$ Rivadeneira recites them with relish.

In the Historia eclesiástica the Jesuit revels in the irony that Henry sought dissolution of his first marriage on the ground of affinity in order to marry

39 La cisma, ed. by Ruiz Ramón, p. 89.

40 La cisma, ed. by Escudero Baztán, p. 138.

41 Philosofía secreta, p. 151.

42 Baltasar de Vitoria, Teatro de los dioses de la gentilidad, pt II (Salamanca: Diego de Cussío, 1623), p. 230.

43 The peacock can be associated with rumour generally. The Aeneid describes rumour as a monster, 'cui, quot sunt corpore plumae, | tot vigiles oculi subter' (IV. 174-183: 'who for the many feathers in her body has as many watchful eyes beneath' (Virgil, Eclogues, Georgics, Aeneid 1-6, trans. by H. R. Fairclough, rev. by G. P. Goold, Loeb Classical Library, 63 (Cambridge, MA: Harvard University Press, 1999), pp. 434-35). My thanks to my friend Anne Wright for drawing my attention to this passage. 
'Ana Bolena, con la cual tenía más estrecho parentesco por vía de afinidad, y más fuertes impedimentos para no se poder casar con ella, que no con la reina doña Catalina'. He sets out several distinct rumours before boldly advancing the most scandalous hypothesis, that '[p]or hija del mismo Enrique era tenida Ana Bolena', the illegitimate daughter of Elizabeth Boleyn. ${ }^{44}$ (Here, then, is the final piece in the puzzle that links Queen Esther to Ana Bolena rather than Catalina: both are raised by men who are not their natural fathers, Mardochai and Tomás Boleno.) Calderón's spectator, calling to mind the most salacious detail of the Juno myth, might well have understood Carlos's allusion to hint at Ana's illegitimate birth and the incestuous nature of the relationship Ana will go on to form with the king. Alternatively, if the switch from the sibling relationship of the myth to the father-daughter incest of the Enrique-Ana pairing seems too violent a distortion, Carlos's allusion might have brought to mind rumours of Anne's incestuous relationship with her brother George, recounted as fact by Rivadeneira. ${ }^{45}$ As keen as Carlos might be to banish these (most probably false) rumours from his mind, the sorrow that besets him as he indulges in his recollections before Dionís allow them subtly to emerge via the allusion that his mind inspires him to draw.

Critics of La cisma have claimed that Calderón omits references to such salacious rumours for the sake of decorum. Ruiz Ramón, for instance, insists that 'Calderón elimina en el tratamiento de Ana todas las alusiones a su sensualidad' ${ }^{46}$ Mackenzie states, similarly, that 'Calderón ignores Ribadeneyra's outrageous allegations of incest'. She notes too that the playwright 'impressively suggests Anne Boleyn's unchaste character, through indirect evidence, poeticized innuendo, half-expressed temptations, eloquently unspoken criticism and sensuously informative imagery', but without linking this observation to specific examples. ${ }^{47}$ Mackenzie might, I suppose, have had this Juno allusion in mind; it is a subtle allusion to Ana's incest, though Carlos intends it as a comment on her beauty and pride. Carlos's allusion is so apposite that it might-and I make this point tentatively only-hint at another scurrilous rumour attaching to Anne: 'tenía seis dedos en la mano derecha'. ${ }^{48}$

The association of the peacock with beauty and vainglory was a commonplace of early modern culture, and equally commonplace was knowledge of the peacock's flaw, its ugly feet. These cause it ultimately to recognize the folly of its pretensions and to experience desengaño, as Ana does herself in La cisma, expressed in her unhistorical valedictory speech (1l. 2626-39). This

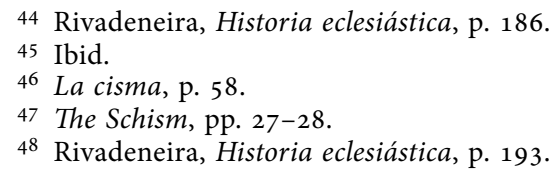


facet of the peacock's iconography is present in the emblem literature of the Golden Age (and the peacock emblem was one to which seventeenth-century dramatists had recourse 'con sorprendente frecuencia'). ${ }^{49}$ As Cull details, it can be found, for example, in Villava's 1613 Empresas espirituales y morales ('Deformes oblita pedes', II, emblem 27, fol. $51^{\mathrm{r}}$ ), in Núñez de Cepeda's 1688 Idea del buen pastor ('Pandit in extremis lumina', emblem 40, pp. 685-86), and in Gómez de la Reguera's 1678 Empresas de los Reyes de Castilla y León ('Vanitas', emblem 18). The ugly feet are the focus of the poem that accompanies Villava's vanagloria emblem of the 'ave de Juno'. It is terribly proud of its beautiful feathers ' $[\mathrm{m}]$ as mírese a los pies y el hilo rompa | [d] eshaga el cerco y su altivez retarde, | [p]ara que ansí se humille quien se ufana | [v]iendo el remate de la vida humana'. The idea is ubiquitous. It is found across the spectrum of Golden Age letters, from the popular proverbs of the age ('míraos a los pies de pavo, desharéis la rueda y garbo') to Don Quijote (II. 42). If the thought processes of the seventeenth-century spectator were similar to mine, the mention of Juno's peacock would call to mind not just incest but ugly feet too. The next stage of the spectator's thinking would, I suggest, link these to the infamous rumours of Anne's (for the age) unwholesome origins and sexual proclivities, and her polydactyly.

\section{Conclusion}

The three allusions on which this essay has focused are fleeting, but I maintain that Calderón's erudite spectator would have noted them and understood them to be ironic. The allusions provide material for the kind of intellectual games in which seventeenth-century Spaniards delighted, allowing them to exercise their mental agility and test their cultural knowledge, especially the classical learning in which formal education consisted. Would the spectator have known to ponder these three allusions in particular? I think so. Aside from a single reference to Apollo (as a rhyme for Margarita Polo), the Esther, Mars, and Juno allusions are the only explicit references to named classical or biblical figures in Act I of La cisma and they are sufficiently spaced out to allow the spectator time to consider their implications. Moreover, as has been demonstrated, the cultural knowledge required to comprehend their irony is relatively rudimentary. Many of Calderón's spectators would certainly not have needed to dig deep into their memories; the Esther, Mars, and Juno tales are basic to Golden Age culture.

The three allusions are Calderón's invention; they have no precedents in his source. The inclusion in La cisma of episodes that are, similarly, the play-

49 John T. Cull, 'Ecos emblemáticos en la obra dramática de Ruiz de Alarcón', in Esplendor y ocaso de la cultura simbólica, ed. by Herón Pérez Martínez and Bárbara Skinfill Nogal (Zamora, Michoacán: El Colegio de Michoacán/CONACYT, 2002), pp. 47-56 (p. 50). 
wright's invention and that reinforce the ironic parallels between the classical and biblical tales and the play's action further suggests that Calderón hoped his audiences would see the relevance of these intertextual references and, in two cases, keep the three Act I analogies in mind as the action developed. Rivadeneira does not mention any occasion when Katherine was denied access to Henry VIII, but Calderón's introduction of this unhistorical episode bolsters the link to the Esther story. Similarly, there is no account in the Historia eclesiástica of the king personally having caught Anne Boleyn with another man, an equivalent to Vulcan's netting of Mars and Venus; but Calderón's insertion of the scene in which Enrique overhears Ana and Carlos discuss their romantic attachment cements the parallel with that classical tale and places Enrique in the role of Vulcan rather than Mars. Finally, there is Ana's desengaño speech (1l. 2626-39), in which she learns the peacock's lesson: using the metaphor of the almond tree (from Ecclesiastes) she recognizes that for all her beauty and ambition she has come to nothing. Rivadeneira allows his Anne no such epiphany.

These allusions, as interesting as they are, are not fundamental to the dramatic success of La cisma. If they are overlooked something will be lost, however, a point Pasco makes in relation to allusion in general: '[s] hould readers remain insensitive to the allusions in whatever they happen to be reading, they will fail to achieve complete understanding', the reader (or spectator) 'will simply not have a satisfactory affective response to the main character and his trials'.$^{50}$ So, in what way might the spectator's understanding of Calderón's characters be deficient without an appreciation of the irony of our three allusions? Their primary effect is, I think, to elicit pity for the characters, who have important truths within their mental reach but fail to grasp them. To apprehend these truths (and to act wisely informed by them) is, we understand, possible, but it requires calm rationalization of a kind hard enough for man to achieve at the best of times and nigh-on impossible when the mind is overcome by passion. This depiction of the severity of the struggle that mankind faces tends to compound the tragic atmosphere that prevails in many of Calderón's dramas: human beings are in theory well equipped to acquire and process knowledge in order to make moral choices, but fallen human nature and the pressure of circumstance can make this a very tall order indeed. The universalizing effect of the classical and biblical referents compounds the apparent pessimism. All of the terrible circumstances Calderón's characters must confront have been encountered before and ' $n$ ] othing under the sun is new' (Ecclesiastes 1. 10). In La cisma, at least, the problem is shown to be the passions, which, according to Aquinas, can play a positive role in man's quest for good, but only when kept under the control of reason. The

50 Allusion, p. 20. 
passions in La cisma are out of control and all too easily cause intellectual inattention that has tragic consequences.

As has been demonstrated, Calderón is insistent in drawing to his spectator's attention the passions afflicting his protagonists. Catalina is 'airada', 'turbada', 'enojada', and Enrique and Carlos are said to be 'triste' on multiple occasions; the king is described as 'triste' eight times up to line $1505 .{ }^{51}$ These passions impede the rational thought that is required for the implications of the allusions drawn by the characters to be teased out by them. Severely afflicted by the passions, these characters show poor judgement. Enrique admits this openly. ${ }^{52} \mathrm{He}$ claims to Volseo that 'las confusiones con que lucho | nunca permiten que se piense mucho' (1l. 1613-14), that his emotional suffering inclines him to make hasty (and therefore ill-judged) decisions. Shortly after this, the king tells himself that his decision to act in contravention of church doctrines he knows to be right can be explained because 'faltó en mí la razón' (1. 1656): his reason has been stunted. That this state is meant to be understood to result from the effect of the passions on his mind is made clear by Volseo. Observing the king's tristitia, the chancellor decides to exploit the intellectual vulnerability he perceives in his master. He chooses a moment when he believes Enrique is distracted by his sadness to trick him into thinking his marriage to Catalina is null and void; aside Volseo comments ' $i[c]$ on qué grave tristeza | divertido ha quedado! | Llegaré descuidado' (1l. 150507). Such comments as these are in keeping with Aquinas's explanations of the interaction of reason and the soul's passions as developed in his treatise 'De passionibus animae'. La cisma contains evidence which indicates that Calderón was familiar with these or similar premodern theories of human psychology. Enrique, it seems, has not as fine an understanding of them as his creator. In words that seem to demonstrate the king's eagerness to be the victim of his own passions (and which, incidentally, echo the title of Aquinas's treatise), Enrique laments 'que las pasiones del alma | ni las gobierna

51 Sadness may sound like a rather muted passion, but for Aquinas '[o]f all the passions, sorrow or sadness (tristitia) is "most properly" said to be a passion [. . .]. Perhaps because the soul is most violently acted upon (pati) when it suffers, the phenomena denoted by "sorrow" and "suffering" overlap considerably' (Miner, Thomas Aquinas on the Passions, p. 188).

52 Interestingly, Enrique resolves this only when references to his sadness cease, after, arguably, he has regained control of his mind, a method for securing his desired union with Ana having been devised. He is a man who likes to create the impression of emotional turmoil, though, in order to justify the immoral choices he makes. Of course, Enrique's self-aware commentary on the absence of reason is the fruit of an act of reason, emphasizing the king's imposture. Enrique is able to describe now the mental block that afflicted him before (and which, as I see it, afflicted Catalina and Carlos in the scenes discussed). See my "La verdad que adoro es la que niego": Symbolism and Sophistry in Calderón's La cisma de Inglaterra', in Bulletin of the Comediantes, 68.1 (2016) (forthcoming), for a discussion of this aspect of the king's character. 
1028 Ironic Allusion in Calderón's 'La cisma de Inglaterra'

el poder, | ni la majestad las manda. | Triste estoy' (1l. 930-33). Of course, Enrique is wrong. Reason, the will, can assert control.

Like modern theories of the unconscious mind, Aquinas's theory of the passions allows premodern man to understand how the human mind can know something without having clear mental 'sight' of it. This is one of several phenomena that in Calderón's drama afford the spectator a powerful impression of the severe limitations in subjection to which man is condemned to live. In La cisma the spectator glimpses this 'unconscious' knowledge through the playwright's masterful ironic allusions.

Christ Church, Oxford

Roy NorTon 